ELORE (ISSN 1456-3010), vol. 20 - 2/2013.

Julkaisija: Suomen Kansantietouden Tutkijain Seura ry.

[http://www.elore.fi/arkisto/2_13/saarinen2.pdf]

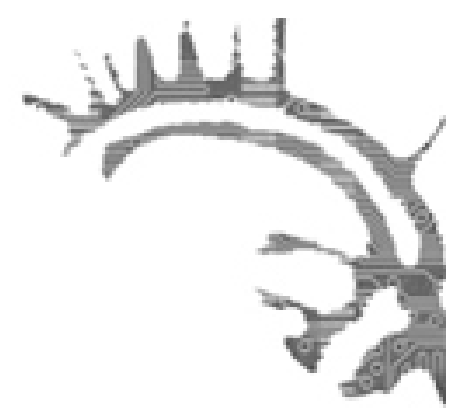

\title{
KIRJA-ARVIO
}

\section{TIETOPAKETTI INTIAANEISTA}

Tuija Saarinen

ANDERSSON, RANI-HENRIK \& HÄMÄLÄINEN, RIKU\& KEKKI, SAARA 2013:

Intiaanikulttuurien käsikirja. Kulttuurin, historian ja politiikan sanastoa. Helsinki:

Gaudeamus. 203 sivua.

Suomalaisten intiaaniharrastus on yllättävän laaja-alaista. Intiaanit ja intiaanikulttuurit kiinnostavat suomalaisia monin tavoin. Maassamme on julkaistu lukemattomia intiaaneja käsitteleviä romaaneja, erilaisia nuortenkirjoja ja sarjakuvia. Intiaaneista on kirjoitettu tietokirjoja ja artikkeleja, ja he näkyvät elokuvien hahmoina. Suomessa toimii myös amatöörimäisiä intiaaniharrastajia sekä intiaaneihin keskittyviä yhdistyksiä ja keskustelupalstoja. Intiaanit ovat olleet myös suomalaisen akateemisen tutkimuksen kohteina 1700-luvulta alkaen. Kiinnostuksesta huolimatta tutkijat eivät kuitenkaan ole saaneet luotua alalle yhdenmukaista, suomenkielistä terminologiaa. Tätä tarvetta täyttämään sopii Intiaanikulttuurien käsikirja, joka esittelee yli 200 keskeistä Pohjois-Amerikan alkuperäiskansoihin liittyvää termiä. Termit on valittu teokseen siten, että ne olisivat yhteisiä kaikille intiaanikansoille, ja että lukija voisi tarkistaa nopeasti tietojaan. Teos tarjoaa johdonmukaisia suomalaisia termejä eräisiin käsitteisiin, joiden käyttö on ollut horjuvaa ja sekavaa. Intiaanikulttuurien käsikirjassa esiintyvää terminologiaa valittaessa on turvauduttu pääsääntöisesti jo aikaisempiin suomennoksiin, mikäli ne ovat ehtineet vakiintua käyttöön. Kaikkea teoksessa ei ole voitu ottaa esille, sillä - kuten jokainen 
ymmärtää - esimerkiksi esinekulttuuri on äärettömän rikas kenttä, jossa on heimokohtaista variaatiotakin.

\section{Heimo VAi KANSA?}

Pohjois-Amerikan alkuperäiskansoista puhuttaessa käytetään usein termejä heimo ja kansa. Intiaanikulttuurin käsikirjan mukaan kyse on lähinnä poliittisesta terminologiasta ja siitä, miten kansa, kansakunta tai heimo halutaan määritellä. Intiaaneilla ei ole ollut teoksen mukaan tarvetta kategorioiden luomiseen, vaan he ovat määritelleet itsensä esimerkiksi lenapeiksi, lakotoiksi tai maiduiksi. Yhdysvalloissa on 560 ja Kanadassa 600 intiaanikulttuuria. Osa haluaa käytettävän mieluummin termiä kansa kuin heimo. Termi kansa on saamassa laajempaa suosiota, sillä sitä pidetään poliittisesti merkittävämpänä. Perinteisesti monet intiaanikansat olivat saman kielen, kulttuurin ja tapojen yhdistämiä, löyhï yhteenliittymiä. Tämän käsityksen mukaan monet kansat voidaan jakaa useisiin pienempiin, melko itsenäisiin yksiköihin eli heimoihin. Esimerkiksi monelle tutut irokeesit voidaan jakaa viiteen eri heimoon. Useiden eri kansojen heimot jaetaan edelleen alaheimoihin tai heimokuntiin. Teos huomauttaakin, että käytäntö on kirjava, ja poliittiset pyrkimykset ovat sekoittaneet sitä entisestään. Yhdysvaltojen ja Kanadan harjoittamien intiaanipolitiikkojen tavoitteena on ollut hajottaa kansojen yhtenäisyyttä jakamalla ne yhä pienempiin osiin. Strategian taustalla lienee ajatus, että pienemmät yksiköt ovat heikompia puolustamaan asemaansa ja valvomaan etujaan.

\section{UNISIEPPARI, UUSMUUNTELUN TULOS}

Intiaanikulttuurin käsikirja esittelee myös sellaisia ilmiöitä, jotka eivät ole perinteisesti kuuluneet intiaanikulttuuriin, mutta jotka ovat nykyaikaisia muuntelun tuloksia. Yksikään kulttuuri - saati sitten Pohjois-Amerikan lukemattomat intiaanikulttuurit - ei ole muuttumaton. Intiaanikulttuureihinkin on siten omaksuttu uusia ilmiöitä, ja ne ovat levinneet heimolta toiselle ja vakiinnuttaneet asemansa. Esimerkiksi unisiepparia (dream catcher) myydään matkamuistoina ja koriste-esineinä eri puolilla maailmaa. Unisieppari on kuitenkin ilmeisesti iältään vain 20-30-vuotias. Intiaanit ovat liittäneet myymiinsä tuotteisiin lukuisia perinteisiksi intiaanitarinoiksi väitettyjä kertomuksia. Unisiepparin on sanottu olleen milloin ojibwa-, lakota-, oneida- tai jonkin muun heimon perinnettä. Panintianistisen toiminnan johdosta unisieppareista on tullut suosittuja koriste-esineitä eri heimojen keskuudessa, ja niiden sanotaan suodattavan unia siten, että pahat unet menevät niiden läpi ja hyvät unet tarttuvat niihin ja menevät nukkujan mieleen. Toisen version mukaan unisieppari pyydystää pahat unet ja päästää vain hyvät unet nukkujan mieleen. Erilaisia kertomuksia tarjotaan erityisesti new age-tarvikkeita ja unisiepparia kauppaavien keskuudessa. Samankaltaisia ilmiöitä, joissa matkailijoille kaupitellaan erilaisia perinteisiksi väitettyjä uusioinnovaatioita tai alkuperäisistä yhteyksistään irro- 
tettuja tuotteita, löytyy myös Suomesta. Harva suomalainen kuljeskelee neljän tuulen hattu päässään, vaikka saamelaismiehen päähineitä myydään Helsingin kauppatorilla.

\section{TIETOA TARPEESEEN}

Intiaanikulttuurin käsikirja puolustaa paikkaansa, sillä suomalaiset tarvitsevat luotettavaa asiatietoa Pohjois-Amerikan intiaaneista. Huonoimmillaan suomalaisten tietämys intiaaneista perustuu populaarikulttuurin yksipuolisiin ja stereotyyppisiin käsityksiin ja johtaa vuoden 1991 kaltaisiin, noloihin tilanteisiin: tuolloin Suomeen rantautui iriadamanteiksi itseään kutsunut ryhmä. Joukko korosti olevansa tutkimusryhmä, joka väitti noudattavansa perinteistä micmac-intiaanien kulttuuria ja testaavansa, kuinka luonnossa voi selviytyä pelkällä keräilyllä. Pohjoisamerikkalainen micmac-heimo sanoutui irti ryhmän toiminnasta ja kävi ilmi, että myöskään ryhmän väitteet intiaanien alkuperäisestä elämäntavasta eivät pitäneet paikkaansa. Suomalainen media ja jopa jotkut tutkijat sen sijaan ottivat ryhmän vastaan kritiikittömästi. Lopulta Suomen viranomaiset peruivat jonkinlaisen new age -uskonnollisuuden innoittaman yhteisön oleskeluluvan maassamme. Teos palveleekin käsikirjana sujuvasti niin toimittajia kuin akateemista tai vaikkapa vielä kasvuiässä olevaa lukijaa, joka tutustuu intiaaneihin seikkailukertomusten avulla.

Teoksessa on runsas kuvitus. Valitettavasti se ei mustavalkoisena tee oikeutta intiaanikulttuureille, joiden rikasta värimaailmaa ihailisi mielellään. Toisinaan teoksessa on toistoa, mutta tämänkaltaisessa kirjassa se lienee väistämätöntä - monien hakusanojen kohdalla on ristikkäisviite toiseen termiin, joka liittyy käsiteltävään ilmiöön. Teoksessa on vieraskielisten termien hakusanasto, mutta ei suomenkielistä. Lukija ei siis sisällysluettelon perusteella näe yhdellä silmäyksellä, millä sivulla esimerkiksi käsite intiaanikesä esiintyy, mutta onneksi pehmeäkantisen kirjan lehteily ja teemasta toiseen siirtyminen käyvät nopeasti. Teoksen eri hakusanat sisältävät myös laajalti tietoa. Yksittäisten hakusanojen sisällön pituus vaihtelee kappaleesta pariin sivuun. Intiaanikulttuurien käsikirja valottaa eri ilmiöiden historiaa ja antaa kirjallisuusviitteitä syvempää perehtymistä varten. Akateeminen lukija ilahtuu loppuun sijoitetusta suomalaisen intiaanitutkimuksen 400-vuotisen historian esittelyluvusta ja laajasta kirjallisuusluettelosta. Epäilemättä teos innostaa uusiakin tutkijoita intiaanien pariin.

Filosofian tohtori Tuija Saarinen toimii tutkijana Suomen Akatemian tutkimusprojektissa Rajaseudun kirjoituskulttuuri ja traditiot Karjalan tutkimuslaitoksella Itä-Suomen yliopistossa. 